\title{
REVISITING ANALYSIS OF THE ROOT CAUSES ON FINANCIAL CRISIS IN ISLAMIC PERSPECTIVE
}

\author{
Mega T.R. Luik ${ }^{1}$ \\ Ahlis Fatoni ${ }^{2}$
}

\begin{abstract}
Steady financial system stability is important in economy. The financial crisis showed a constantly recurring problem that has not been resolved completely. Macro prudential policy, which became the term savior after the subprime mortgage crisis was essentially a temporary not eliminate the root causes of the problems of the financial crisis. This study attempts to revise the root causes of the financial crisis in the perspective of Islam by using three approaches namely Vector Error Correction Model (VECM), Error Correction Model (ECM), and Distributed-Lag Autoregressive (ARDL). The result of this study that the consistence of ribâ (interest rate) variable as the main factor of crisis; ribâ increases the inflation and decreases the growth. The IRF (impulse response function) result and FEVD (forecast error varian decomposition) show $21.87 \%$ interest rate (INT) increases the inflation and decreases the growth by $9.5 \%$. Meanwhile, profit-loss sharing (PLS) variable contributes to decreases the inflation by $0.02 \%$ and increases the growth by $0.61 \%$. Reciprocally, with ECM approach, interest rate (INT) has positive effect to inflation and negative effect to growth (financial crisis) vice versa PLS significantly has negative effect to inflation and positive effect to growth, whereas ARDL approach shows that PLS increases the growth at long and short run but also increases the inflation at long run. Another conventional variable consistently contributes to financial crisis according to all approaches; volatile food (VFP) and administered price (ADM).
\end{abstract}

Keywords: Financial Crisis, Inflation, Growth, Ribâ, Profit-loss sharing JEL Classification: E44, E51, G01, G21

Received : September 18, 2017

Revised : April 17, 2018

Accepted : May 3, 2018

1. Master student in Economics, Kulliyah of Economics and Management Sciences, International Islamic University Malaysia, Kuala Lumpur, Malaysia. Email : megaluik@ gmail.com.

2. Ph.D candidate in Islamic Banking and Finance, International Islamic University Malaysia, Kuala Lumpur, Malaysia. Email : ahlisfatoni@gmail.com. 


\section{INTRODUCTION}

The global financial crisis poses the same threat to every country regardless of whether the country is rich or poor, big or small. The financial crisis can come from within and outside the country, from the public and private sectors, having various shapes and sizes, spreading very fast with no recognition of borders and requiring immediate and comprehensive policy responses as well as global policy coordination (Claessens \& Kose, 2013). Since the end of the golden currency system in 1915, the financial crisis has always occurred in various parts of the world that led to the great depression in 1930 (Davies, 1996). The inception of the Bretton Woods Agreement in 1944 where the fixed exchange rate system with the US dollar as the international currency backed by gold (gold exchange standard), gave a good impact during the period 1950-1972 to the international financial stability (Ascarya, 2009).

The end of the Bretton Woods Agreement at 1971 unilaterally by the Americans has had a significant impact on the instability of the global financial system, a system that cannot be separated from volatility, exchange rate fluctuations, excessive credit expansion, asset price bubbles, imbalances and financial system vulnerability so that the financial crisis erupted again in various countries (Ascarya, 2013). According to (Laeven \& Valencia, 2013), 431 crises occurred during the 19702011 period such as 147 banking crises, 218 currency crises and 66 foreign debt crises, including 68 twin-crisis and 8 tripled-crisis.

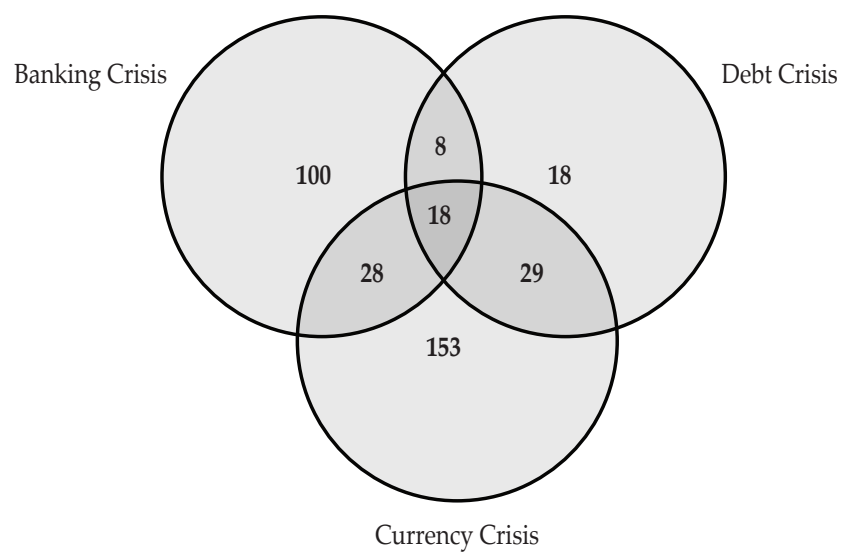

Source: Laeven and Valencia (2013), with correction

Figure 1.

Simultaneous crisis period $1970-2011$

Based on International Monetary Fund (IMF) the average banking crisis resulted in cost losses between $14-15 \%$ of GDP, whereas if the banking crisis occurred simultaneously with the currency crisis then the loss increased to 17-19\% of GDP and takes time for recovery from this condition for 3-5 years. The cost of bank restructuring costs about $10 \%$ of GDP, while developing countries cost more 
than $30 \%$ of GDP such as Argentina, Chile, Uruguay and Kuwait (Iinternational Monetary Fund,1998). Indonesia also experienced a severe multidimensional crisis in 1997-1998 where the inflation increased to $64 \%$ and the rupiah weakened from Rp 2.600/USD to reach Rp 11.000 /USD followed by economic growth which slowed down to $13.1 \%$. All economic sectors at the time deal with a very significant slowdown, the depreciation of the rupiah also caused the government to bear the debt of 60 billion USD in November 1997 (Ascarya, 2013). Indonesia suffered huge losses at fiscal cost of $56 \%$ of GDP that at the same time also lost output at $67.9 \%$ of GDP (Laeven \& Valencia, 2008).

The recurrent financial crisis indicates that problem solving has not reached the root of the problem with the policies implemented. Furthermore, the financial crisis occurs due to structural failure in various countries, due to differences in the rug system as well as differences in the level of economic development not caused by cyclical or managerial failure (Lietaer, et al., 2009).

According to Islamic perspective, Allah SWT states that all destruction that occurs on the surface of the earth is the result of human hands as in the word of Surah Al-Rum verse 41. Islam as the true, comprehensive, and universal religion has the right rules and solutions to various problems on earth include financial crisis. Allah has forbidden ribâ (usury), gharar (uncertainty), maysir (gambling / speculation) in every transaction that today has merged with conventional financial system such as interest rate system, fiat money, frictional reserve requirement, securitization and so forth. Due to any violation of Allah's rule will come to consequences for imbalances and injustices in the economy, in economic terms, this condition is known as decoupling occurring between financial and real sector. There is no doubt that the current financial system has been fundamentally flawed that it may cause instability and financial crises (Ascarya, 2013). A policy will be meaningful if the fundamental problem is well understood.

Thus, this study aims to revisit the analysis of the root causes on financial crisis in Islamic perspective and its impact on output growth and inflation in Indonesia.

\section{RELATED LITERATURE}

\subsection{Causes of the Financial Crisis According to Islam}

According to Islam, the financial crises are divided into two main causal factors, namely natural and human error. The natural factors such as natural disasters and business cycles while human error factors such as the existence of imbalance between financial and the real sector caused by human disobedience in carrying out orders and away from the ban of Allah SWT. Especially the main pillars in the financial system, among others; the prohibition of ribâ (interest), the ban of maysir (speculation) and the ban of gharar (uncertainty) in many forms in the current financial system (Ascarya, 2013).

Crisis caused by natural factors is recognized in Islam and this is a common thing, because Allah subhanahu wata'ala has told it in the Qur'an:

[He said], "Yusuf, O man of truth, explain to us about seven fat cows eaten by seven [that were] lean, and seven green spikes [of grain] and others [that were] dry - that I may return to the people; perhaps they will know [about you]. [Yusuf] said, "You will plant for seven years consecutively; and what you harvest leave in its spikes, except a 
little from which you will eat. Then will come after that seven difficult [years] which will consume what you saved for them, except a little from which you will store. Then will come after that a year in which the people will be given rain and in which they will press [olives and grapes]." (Q.S. Yusuf [12] : 46-49)

Ascarya (2015) explains that the story of the prophet Yusuf (p.b.u.h) is an example of a crisis that occurs due to natural phenomena, but if it can be well organized, then the impact of the crisis can be minimized to be smaller. In a hadith from Anas bin Malik Radhiyallahu anhuma he said:

"There has been an increase in prices during the time of the Prophet sallallaahu 'alahi wasallam, then people say: "O Messenger of Allah, prices have soared, then set the standard price for us." He then said: "Allah is the one who determines the price, which narrow and clear, and He who gives rizq. Truly, I hope that when I meet Allah there is no one who holds my responsibility for blood and wealth." (Ibnu Majah No. 2191)

In addition, when Medina suffered from drought causing food prices increased, but the Prophet did not control the price and the Messenger of Allah prayed to Allah SWT for rainfall (Al-Thabrani in Al-Mu'jam Al-Ausath narrated by Annas bin Malik). According to the hadith above, that the Messenger of Allah solved the crisis directly to the root of the problem, which the drought occurred because there was no rain, so the Prophet requested that the rainfall, not intervene in the market and control the price.

Ascarya (2015) describes the forms of violations included in the Human error in detail as follows: 1) interest rate system, 2) fiat money system, 3) frictional reserve banking system, 4) leverage system, 5) derivative, and 6) credit card system. Furthermore, Maysir violations include: 7) speculation in stock trading, 8) speculation in foreign exchange trading, 9) speculation in commodity trading and 10) speculation in real estate trading. As for gharar violations, such as 11) complexity in transactions, 12) complexity in the structure of financial products, 13) securitization, 14) hedging and 15) Insurance products. Besides other deviant behaviors that can cause crises such as self-interest, monopoly, stockpiling, price control, manipulation, asymmetric information, injustice, greed, and other.

\section{A. Ribâ}

Ribâ by language means, "To increase". Then everything that grows is called ribâ. Meanwhile, the term ribâ means adding a burden to the debtors (known as ribâ dayn) or adding a dose when exchanging six commodities (gold, silver, wheat, sya'ir, dates and salt) of the same type, or exchange exchange gold with silver and food with food in a non-cash fashion (known as ribâ ba'i) (Tarmizi, 2013).

Ribâ is a disease in society. According to the experts, ribâ has existed since people know about money (gold and silver). The ribâ has been known by several periods of civilization such as the Sumerian, Babylonian and Asy'uriya civilizations in Iraq, the Farao civilization in Egypt and the Hebrew Jewish civilization (Al Umrani, 2007). It has been contained in the Qur'an, surah An-nisaa verse 160-161 that the behavior of eating ribâ was done by the Jews and Allah has forbidden them from eating ribâ. Ribâ began to spread to the Arabian Peninsula region by the Jews who later practiced by the Quraysh of ignorance (Al Misri, 2001). 


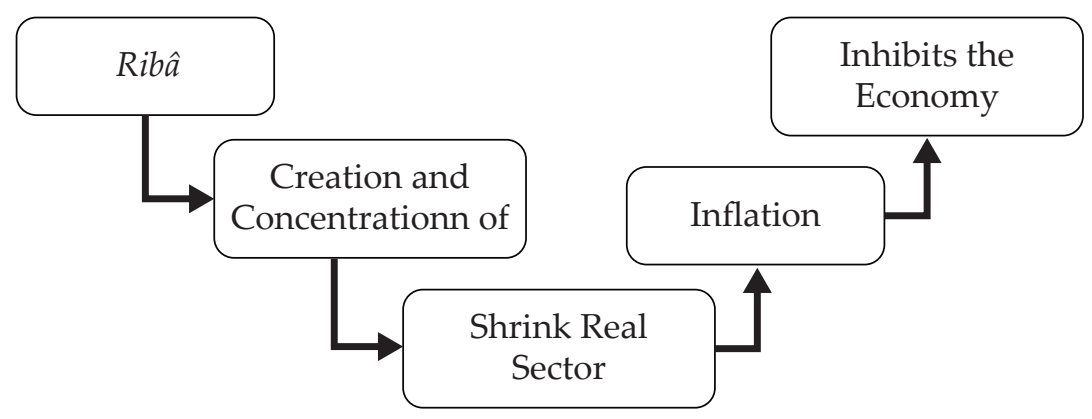

Source: Sakti (2007)

Figure 2.

Implications of Interest Rates on the Economy

The existence of an interest rate system, minimum mandatory reserves, fiat money, money as a commodity and the legality of speculation leads to the creation of new money and concentrated money in the financial sector in the conventional economic system. This causes stagnation in the real sector, resulting in excess of money supply and the slowing of the real sector thus causing inflation (Ascarya, 2015).

In Figure 2 above, it can be seen that in today's conventional economic system, the ribâ system in banking and the allowance of speculation leads to the creation of zero money without backing up and the absorption of money in the monetary sector to seek profit in the absence of risk. As a result, money or investments that should be channeled into the real sector for productive purposes are hampered largely into the monetary sector resulting in the inclusion of real sectors. The creation of money without any added value to the real sector will lead to inflation. In the end, this will have an impact on slowing economic growth.

In contrast, the Islamic economic system, where ribâ (interest rates), gharar (uncertainty) and maysir (speculation) are prohibited to promote a well turned and conducive investment climate. Given the profit sharing, system in the business will affect the distribution of wealth and income is fairer. This clearly provides a good stimulus for developing more productive real sector, expanding field and employment opportunities and driving the pace of the economy. 


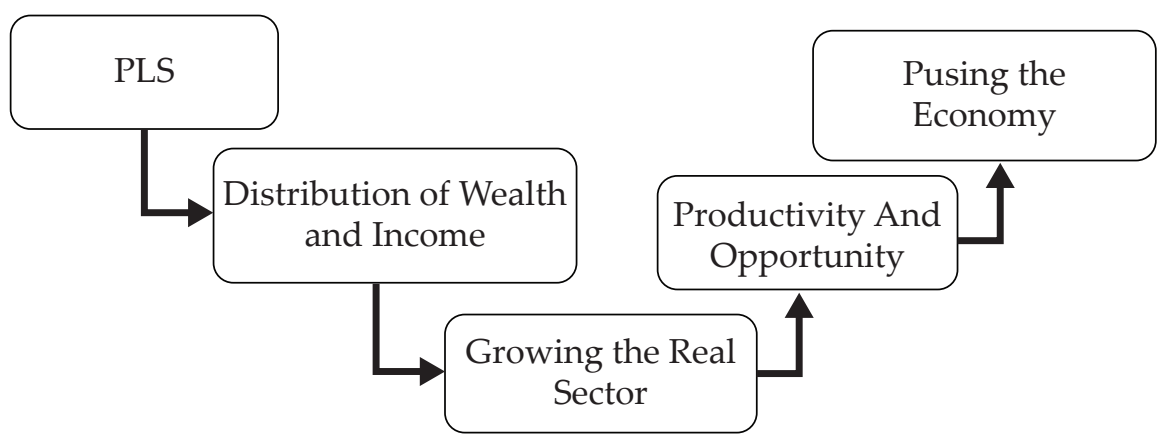

Source: Sakti (2007)

Figure 3.

Profit Sharing Impact on the Economy

There is no doubt that the ribâ is haram in Islam, where Allah has justified the sale and purchase and forbid the ribâ (Al Baqarah: 275). Allah also commands the subjects of the ribâ to cease from this activity (Al Baqarah: 278). Moreover, Allah also threatened to fight against those who keep running the activity of ribâ (AlBaqarah: 279). Ribâ has an enormous impact both on human resources, Inflation, impeding the rate of economic growth, creating social inequality and the main factors causing the crisis. Ribâ destroys human resources because it lowers human productivity in doing business (work) because the true mechanism of ribâ makes the subjects of ribâ obtain results without doing a real effort. The ribâ block the world's piety because the people's good will not be achieved without trade, work and development (Ar Rozi in Tarmizi, 2013).

Ribâ can also cause inflation because to obtain a business capital a producer must pay interest as a lending service in a conventional financial institution. Automatically, the manufacturer will calculate interest on the loan as the operating cost. As a result, the price of the finished good will become more expensive, economically known as the cost-push inflation or inflation caused by cost factors in production. As if interest rates falling demand for credit will rise, then the amount of money in circulation will increase, this can lead to inflation, demand-driven inflation (demand-pull inflation). More broadly, inflation can cause people's purchasing power to decline gradually to become hyperinflation in an instant and this is a very big tyranny. Ribâ is an obstacle to the pace of economic growth, in line with that of J.M Keynes, that 'Interest rates discourage economic growth, as interest rates block the speed of capital to freedom. If interest rates may be abolished then capital will move in rate and grow quickly' (Al Asyqar in Tarmizi, 2013)

Ribâ can create social inequality because rich people get richer by consuming ribâ treasure and poor people will get poorer by being trapped in ribâ loan. Therefore, Islam clearly prohibits the ribâa and obliges zakat, whereas zakat is an Islamic financial instrument can increase the purchasing power of the poor and other six asnaf also seek to wipe the gap between mustahik and muzakki. Further ribâ is the main cause of the global economic crisis. The 2008 crisis still in memory that the resulted of ribâwi practice, low interest rates during 2002-2006 in the United 
States resulted in high demand for property loans, but in early 2006 there was a drastic change in which interest rates increased and property prices declined, bad loans and one by one financial institutions falling bear heavy losses (Ahmed, 2009).

\section{B. Gharar}

Gharar by language means risk, deception and fall or treasure into the abyss of destruction. According to the term jurisprudence, gharar means unclear sale. The nature of gharar is when one earns a profit while the other loses, because gharar is one form of Maisyir (Tarmizi, 2013). Gharar activity is forbidden in Islam, as His word:

"O you who have believed, indeed, intoxicants, gambling, [sacrificing on] stone alters [to other than Allah], and divining arrows are but defilement from the work of Satan, so avoid it that you may be successful. Satan only wants to cause between you animosity and hatred through intoxicants and gambling and to avert you from the remembrance of Allah and from prayer. So will you not desist?" (Al Maidah : 90-91)

One of the wisdom of banning gharar is because it can be the cause of economic destruction of a country even the world. Once again, the global crisis of 2008 was also due to this practice with a modern form but essentially the same. Gharar on the exchange cause the creditor to submit a property certificate as collateral in the bank and by the bank the certificates are used as underlying of securities (securitization). After being insured and entered the international bourse characterized by gharar and gambling activities such as short selling, option, buy on margin, futures and others then suburban mortgage-based securitization are purchased by financial institutions in the world. Therefore, when there is a bad debt in the property sector, the global economic crisis was not dammed. Thus, not only America but the whole world is agitating this economic crisis turmoil. Al Misri (2001) asserted that the causes of the global crisis in 2008 include gharar and qimar.

\section{Maysir}

Maysir means getting things easily without hard work or earning money without working. Maysir is everything related to gambling, gambling and risky games (Ascarya, 2015). There are two Maysir prohibitions: first, maysir is forbidden because it contains elements qimar like two or more people who do a game and each spend a sum of money to stake, so if he won then he will take all the money bet and if he lost then he will bear the loss by losing money already at stake. Therefore, it is same as gharar. Second, the game that is forbidden though not accompanied premises payment of money, also including maysir. According to some salaf scholars when observed about maysir then the answer is "all games that neglect themselves from prayer and zikrullah including maysir. This is according to Ibn Taymiyyah and Ibn Qayyim and the majority of scholars, it is forbidden to maysir not because it contains elements of speculation but can cross people from prayer, zikrullah, and cause hatred and hostility, while the function of money is only a reward to attract them in the game (Tarmizi, 2013). 
Maysir is an activity prohibited in Islam as contained in the Qur'an, sura baqarah verse 219 and Surah Al Maida verses 90-91.

"They ask you about wine and gambling. Say, "In them is great sin and [yet, some] benefit for people. But their sin is greater than their benefit." And they ask you what they should spend. Say "The excess [beyond needs]." Thus Allah makes clear to you the verses [of revelation] that you might give thought". (Al Baqarah : 219)

The practice of maysir may lead to decoupling between the financial sector and the real sector, where the financial sector moves quickly without any equilibrium with the real sector (Ascarya, 2015).

\subsection{Previous Research}

Some of the most recent researches related to the financial crisis from Islamic and Conventional perspectives are summarized as follows.

Ascarya (2015), mentioned that the Islamic economic thinkers agreed that the causes of the global financial crisis are Ribâ, gharar and maysir are contained in financial instruments, such as interest-based financing, financing to risk shifting, adjustable-rate mortgage, moral hazard, derrivative financial, financial enginering, sale of debts, and sort sales in stock. This research was done by some methodologies that are SEM, VAR/VECM, and ANP. Furthermore, both SEM and VAR/VECM used same variable, which are External, Governance, Monetary System, Fiscal System, and Crisis. Adel Ahmad (2010) with qualitative methodology in Global Financial Crisis: An Islamic Finance Perspective also addressed that the root of crisis problems is ribâ, speculation, selling debt, and short selling and providing a fair and effective system.

Mirakhor and Slomo (2010) analyzed in The Global Financial Crisis and its Implications for the Islamic Finacial Industries that the cause of the crisis is the fastgrowing credit growth. Other causes; Easy money, uncontrolled credit and debt growth, lack of regulation and oversight, the complexity of innovation and the uncertainty of financial products, the mismanagement of risks, no transparency, lenders, and high leverage. In addition, financial crises occur because there is not a fair share of risk between the bank and the customer (interest). Besides, the ability of money creation and the use of money by the central bank and commercial bank can lead to bubble speculation in the future (Dar and Hakeem, 2012) in The Global Financial Crisis and The Islamic Financial Solution.

Furthermore, Bianchi and Mendoza (2011), which used qualitative analysis with some variable, that are calibration, borrowing decision, asset return, incidence and magnitude of financial crisis, long-run business cycles, properties of macroprudential policies, welfare effect, and sensitivity effects. The result of the research is; to prevent the financial crisis from happening can be done by enforcing macro prudential policy, because with the existence of macro prudential policy related to credit externalities which can result in asset sale assurance and detrimental macroeconomic situation widely. 


\section{METHODOLOGY}

\subsection{Types and Data Sources}

This research uses quantitative method with three approaches namely Vector Error Correction Model (VECM), Error Correction Model (ECM) and Auto Regressive Distributed Lag (ARDL). Data required in the form of monthly time series data from January 2004 to December 2015 obtained from several sources, such as Central Bureau of Statistics (BPS), Indonesian Economic and Finance Statistics of Bank Indonesia (SEKI-BI), Islamic Banking Statistics (SPS), Financial Services Authority (OJK) and Ministry Energy and Mineral Resources (KESDM).

\subsection{Variables and Operational Definitions}

The variables used with the VECM, ECM and ARDL methods and their definitions are as follows:

Table 1.

Variables and Operational Definitions

\begin{tabular}{|c|c|c|}
\hline & Conventional & Islamic \\
\hline Crisis & \multicolumn{2}{|c|}{ Inflation, growth } \\
\hline Bahavior & Expectations & Without expectations \\
\hline External & International Currency System & Gold Money \\
\hline $\begin{array}{l}\text { Monetary \& } \\
\text { Macroprudential }\end{array}$ & $\begin{array}{l}\text { Interest rate, fiat money, fractional } \\
\text { reserve }\end{array}$ & PLS, Islamic Money, narrow banking \\
\hline Fiscal & $\begin{array}{l}\text { Weak management strategy, } \\
\text { fluctuations in the price of staple } \\
\text { foods }\end{array}$ & $\begin{array}{l}\text { Good management strategy, the } \\
\text { stability of the price of staple foods }\end{array}$ \\
\hline Governance & The existence of price controls & Without the price controls \\
\hline
\end{tabular}

\section{A. Behavior}

XINFL: Expected inflation, is the monthly inflation rate, the Consumer Price Index, from the previous period sourced "Consumer Price Index and Monthly Inflation of Indonesia", BPS.

\section{B. Exsternal}

EXCH : Rupiah exchange rate nominal to USD obtained from SEKI-BI

GOLD : The single currency or gold price index obtained from SEKI-BI

\section{Monetary \& Macroprudential}

INT: Monthly interest rate of conventional deposits obtained from SEKI-BI and OJK

PLS: The monthly profit sharing rate of syariah deposits obtained from SPS-BI and OJK

FM : Fiat Money, initial money creation issued by central bank or money supply (M0) obtained from SEKI-BI 
FRB : fractional reserve banking is the difference between M2 and M0 (M2-M0) obtained from SEKI-BI

IM : Islamic Money, Money circulating in Islamic perspective proxied with M1 obtained from SEKI-BI

\section{Fiscal}

VFP : Volatile food Price, monthly food price index for rice obtained from SEKI-BI

\section{E. Governance}

ADM : Administred Price, the price of fuel oil (BBM) premium obtained from KESDM

\section{F. Crisis}

INFL : "Indonesia Consumer Price Index and Monthly Inflation", BPS.

GRO : "Monthly Production Index of Large and Medium Industry", BPS.

\subsection{Empirical and Theoretical Models}

\section{A. Vector Autoregressive (VAR) / Vector Error Correction Model (VECM)}

The VAR method treats all variables symmetrically regardless of the dependent and independent variables (Sims in Gujarati, 2004). According to Enders \& Granger (2004), in general VAR model can be written as follows :

$$
Y_{t}=A_{0}+A_{1} Y_{t-1}+A_{2} Y_{t-1}+\ldots+A_{p} Y_{t-p}+\varepsilon_{t}
$$

Where:

$P=$ Number of variables in the system of equations

$A o=$ Vector $(\mathrm{n} \times 1)$ containing $\mathrm{n}$ of each variable of VAR

$A_{i}=$ Dimension coefficient matrices $(\mathrm{n} \times \mathrm{n})$

$\varepsilon_{\mathrm{t}}=$ Vector $(\mathrm{n} \times 1)$ of error term

In VAR analysis, the data used must be stationary or do not contain the root unit at the level. But in fact, time series data is generally not stationary at the level, then will be stationary at the first difference. This causes long-term information to be lost. To anticipate the loss of such long-term information, the VECM model can be used. This is done when there is at least one cointegrated equation (Enders \& Granger, 2004).

The VECM model according to Enders \& Granger (2004) can be written mathematically as follows:

$$
\Delta X_{t}=\mu_{t}+\prod x_{t-1} \sum_{i-1}^{k-1} \Gamma_{i} \Delta Y_{t-1}+\varepsilon_{t}
$$


Where:

$X_{k}=$ is $\mathrm{k}$ selected endegenous variable, specific for each model

$\varepsilon_{k}=$ interference or zero error value and variance-covariance constant

Thus the specification of the VECM model formed is in the Inflation Model: $\mathrm{x}_{k}=$ [Crisis (INFL), Behavior (XINFL), External (EXCH, GOLD), Monetary and Macroprudential (INT,PLS, IM, FM , FRB), Governance (ADM), Fiscal (VFP)] and Output growth model:

$\mathrm{x}_{k}=[$ Crisis (GRO), Behavior (XINFL), External (EXCH, GOLD), Monetary and Macroprudential (INT,PLS, IM, FM , FRB), Governance (ADM), Fiscal (VFP)]

\section{B. Error Correction Model (ECM)}

Error correction model aims to solve the problem of time-series data problem, which is not stationary and fake regression. This becomes important, so that the results of the regression are not doubtful or is called spurious regression. To overcome this problem requires emphasis and attention to the statistical properties of non-stationary time series. According to Enders \& Granger (2004), a time series is said to be stationary for any period of time $t$ and $t-s$ if it satisfies:

$$
\begin{aligned}
& \text { 1. } E\left(Y_{t}\right)=E\left(Y_{t-s}\right)=\mu \\
& \text { 2. } E\left[\left(Y_{t}-\mu\right)^{2}\right]=E\left[\left(Y_{t-s}-\mu\right)^{2}\right]=\sigma_{y}^{2} \text { or } \operatorname{var}\left(Y_{t}\right)=\operatorname{var}\left(Y_{t-1}\right)=\sigma_{y}^{2} \\
& \text { 3. } E\left[\left(Y_{t}-\mu\right)\left(Y_{t-s}-\mu\right)\right]=E\left[\left(Y_{t-s}-\mu\right)\left(Y_{t-j-s}-\mu\right)\right]=\gamma_{2} \\
& \text { or } \operatorname{cov}\left(Y_{t}, Y_{t-s}\right)=\operatorname{cov}\left(Y_{t-j}, Y_{t-j-s}\right)=\gamma_{2}
\end{aligned}
$$

In addition, the problem of consistency differences between short-term and long-term forecasting results by the disequilibrium proportion in one period is corrected in the next period so that no information is omitted until use for longterm forecasting (Insukindro, 1997). The general form of the error correction model is as follows (Enders \& Granger, 2004):

$$
\Delta y_{t}=\alpha_{0}+\alpha_{1} \Delta z_{t}+\gamma e_{t-1}+\varepsilon_{t}
$$

or

$$
\Delta y_{t}=\alpha_{0}+\alpha_{1} \Delta z_{t}+\gamma\left(y_{t-1}-\beta_{0}-\beta_{1} z_{t-1}\right)+\varepsilon_{t}
$$

Where $\alpha_{1}$ is the short-run coefficient and $\gamma$ is the error correction term (ECT). Thus, the ECM model specifications for the short term in this study are:

$$
\begin{aligned}
& \Delta \mathrm{INFL}_{\mathrm{t}} \text { or } \Delta \mathrm{GRO}_{\mathrm{t}}=\alpha_{0}+{ }_{\alpha 1} \Delta \mathrm{XINF}_{\mathrm{t}}+\alpha_{2} \Delta \mathrm{EXCH}_{\mathrm{t}}+\alpha_{3} \Delta \mathrm{GOLD}_{\mathrm{t}}+\alpha_{4} \Delta \mathrm{INT}_{\mathrm{t}}+ \\
& \alpha_{5} \Delta \mathrm{PLS}_{\mathrm{t}+} \alpha_{6} \Delta \mathrm{FM}_{\mathrm{t}}+\alpha_{7} \Delta \mathrm{FRB}_{\mathrm{t}}+\alpha_{8} \Delta \mathrm{IM}_{\mathrm{t}}+\alpha_{9} \Delta \mathrm{ADM}_{\mathrm{t}}+\alpha_{10} \Delta \mathrm{VFP}_{\mathrm{t}}+\gamma \mathrm{e}_{\mathrm{t}-1}+\varepsilon_{\mathrm{t}}
\end{aligned}
$$


As for the long-term ECM model:

$\mathrm{INFL}_{\mathrm{t}}$ or $\mathrm{GRO}_{\mathrm{t}}=\beta_{0}+\beta_{1} \mathrm{XINFL}_{\mathrm{t}}+\beta_{2} \mathrm{EXCH}_{\mathrm{t}}+\beta_{3} \mathrm{GOLD}_{\mathrm{t}}+\beta_{4} \mathrm{INT}_{\mathrm{t}}+\beta_{5} \mathrm{PLS}_{\mathrm{t}}+$ $\beta_{6} \mathrm{FM}_{\mathrm{t}}+\beta_{7} \mathrm{FRB}_{\mathrm{t}}+\beta_{8} \mathrm{IM}_{\mathrm{t}}+\beta_{9} \mathrm{ADM}_{\mathrm{t}}+\beta_{10} \mathrm{VFP}_{\mathrm{t}}+\varepsilon_{\mathrm{t}}$

\section{Autoregressive Distributed Lag (ARDL)}

The regression model that includes the value of a variable that describes either the present value or the lag of the independent variable in addition to the model entering the lag value of the dependent variable as one of the explanatory variables is called Autoregressive Distributed Lag (ARDL). This model can distinguish shortterm and long-term responses from dependent variables to one unit of change in the value of explanatory variables (Gujarati, 2004).

The general model of ARDL (Pesaran and Shin, 1995) is

$$
\begin{aligned}
& y_{t}=\alpha_{0}+\alpha_{1} t+\sum_{i=1}^{p} \emptyset_{i} y_{t-1}+\beta^{\prime} x_{t}+\sum_{i=0}^{q-1} \beta_{i}^{*} \Delta x_{t-i}+u_{t}, \\
& \Delta x_{t}=P_{1} \Delta x_{t-1}+P_{2} \Delta x_{t-2}+\ldots+P_{s} \Delta x_{t-s}+\varepsilon_{t}
\end{aligned}
$$

Where $\mathrm{x}_{\mathrm{t}}$ is a dimension $k \mathrm{I}(1)$ ie unintegrated variables in it. $u_{t}$ and $\varepsilon_{\mathrm{t}}$ sequentially not correlated with the mean interference of zero and constant variance-covariances, and $\mathrm{P}_{i}$ is coefisien matrix $k \times k$ such as VAR process at stabil $\Delta \mathrm{x}_{\mathrm{t}}$

Thus, the ARDL model specification in this research is for the inflation and growth model:

$$
\mathrm{Y}_{\mathrm{t}}=\beta_{0}+\beta_{1} \mathrm{y}_{\mathrm{t}-1}+\ldots+\beta_{\mathrm{p}} \mathrm{y}_{\mathrm{t}-\mathrm{p}}+\alpha_{0} \mathrm{X}_{\mathrm{t}}+\alpha_{1} \mathrm{X}_{\mathrm{t}-1}+\alpha_{2} \mathrm{X}_{\mathrm{t}-2}+\ldots+\alpha_{\mathrm{q}} \mathrm{X}_{\mathrm{t}-\mathrm{q}}+\varepsilon_{\mathrm{t}}
$$

Where:

Yt are Inflation (INFL) and growth output (GRO)

$X$ are XINFL, EXCH, GOLD, FM, IM, FRB, ADM, VFP, INT, and PLS $\varepsilon_{\mathrm{t}}$ is an Error

\section{FINDING AND DISCUSSION}

\subsection{Vector Error Correction Model Serial Test}

\section{A. Stationary Test}

The test method used in the data stationary test in this study is the ADF (Augmented Dickey Fuller) test using the significant level. All variables used in this study stationary at first difference level. 
Table 2.

Stationary Test

\begin{tabular}{lcccc}
\hline \multirow{2}{*}{ VARIABLE } & \multicolumn{2}{c}{ ADF Value } & \multicolumn{2}{c}{ Mc Kinnon Critical Value } \\
\cline { 2 - 5 } & Level & 1st Diff & Level & 1st Diff \\
\hline GRO & $1,818,282$ & $-1,239,228$ & $-2,883,579$ & $-2,881,978$ \\
INFL & $-0,221329$ & $-9,901,627$ & $-2,881,685$ & $-288,183$ \\
XINFL & $-2,722,656$ & $-9,675,462$ & $-2,577,668$ & $-288,183$ \\
IM & $-1,341,628$ & $-2,707,124$ & $-2,883,579$ & $-2,578,601$ \\
FM & $-1,506,971$ & $-3,005,025$ & $-2,883,753$ & $-2,883,753$ \\
FRB & $-0,620859$ & $-1,143,884$ & $-2,881,978$ & $-2,881,978$ \\
PLS & $-259,000$ & $-1,679,359$ & $-2,577,668$ & $-288,183$ \\
INT & $-3,214,589$ & $-4,651,936$ & $-288,183$ & $-288,183$ \\
GOLD & $-1,041,541$ & $-1,092,528$ & $-2,881,685$ & $-288,183$ \\
EXCH & $-0,471903$ & $-106,649$ & $-2,881,685$ & $-288,183$ \\
ADM & $-0,221329$ & $-9,901,627$ & $-2,881,685$ & $-288,183$ \\
VFP & $-2,288,926$ & $-834,036$ & $-2,881,978$ & $-2,881,978$ \\
\hline
\end{tabular}

\section{B. VAR Stability Test}

The stability test results in Table 3 show that the INFL model is stable in lag 9 and the GRO model is stable at lag 10.

Table 3.

VAR Stability Test

\begin{tabular}{cccc}
\hline No & Model & Modulus & Max Lag \\
\hline 1 & INFL & $0.070757-0.979685$ & 9 \\
2 & GRO & $0.090612-0.992960$ & 10 \\
\hline
\end{tabular}

\section{Optimum Lag Test Results}

The test results in Table 4 show the optimum lag variation of the five criteria, ranging from 0 (zero) to 6 (six). The optimum lag on the LR criterion is 6 , SC at 0 , while AIC, HQ, and FPE give the number 1 as the optimum lag on the INFL model. 
Table 4.

Optimum Lag Test Inflation Result

\begin{tabular}{ccccccc}
\hline Lag & LogL & LR & FPE & AIC & SC & HQ \\
\hline 0 & $-218,926$ & NA & $7,95 \mathrm{E}-13$ & $3,356,584$ & $3.591035^{*}$ & $3,451,859$ \\
1 & $1,853,826$ & 433,329 & $\mathbf{1 . 4 6 e - 1 3 ^ { * }}$ & $\mathbf{1 . 6 5 6 3 7 6 ^ { * }}$ & $4,469,788$ & $\mathbf{2 . 7 9 9 6 7 8 ^ { * }}$ \\
2 & $1,272,985$ & $1,810,024$ & $1,80 \mathrm{E}-13$ & $1,835,059$ & $7,227,433$ & $4,026,389$ \\
3 & $2,453,279$ & $1,774,749$ & $2,04 \mathrm{E}-13$ & $1,878,425$ & 984,976 & $5,117,782$ \\
4 & $3,323,997$ & $1,169,432$ & $3,93 \mathrm{E}-13$ & $2,373,727$ & $1,292,402$ & $6,661,111$ \\
5 & $4,420,362$ & $1,296,432$ & $6,14 \mathrm{E}-13$ & $2,539,617$ & $1,566,887$ & $7,875,029$ \\
6 & $6,140,451$ & $\mathbf{1 7 5 . 7 7 5 5 ^ { * }}$ & $4,57 \mathrm{E}-13$ & $1,794,963$ & $1,750,318$ & $8,178,401$ \\
\hline
\end{tabular}

As for the GRO model, the results in Table 5 shows the optimum lag variation of the five existing criteria, ranging from 0 (zero) to 6 (six). The optimum lag on the LR criterion is 6 , SC at 0 , while AIC, HQ, and FPE give the number 1.

Table 5.

Optimum Lag Test Growth Result

\begin{tabular}{ccccccc}
\hline Lag & LogL & LR & FPE & AIC & SC & HQ \\
\hline 0 & $-416,2779$ & NA & $1,42 \mathrm{E}-11$ & 6,237634 & $\mathbf{6 . 4 7 2 0 8 5 ^ { * }}$ & 6,332909 \\
1 & $-171,7744$ & 446,1743 & $\mathbf{2 . 3 5 e - 1 2 ^ { * }}$ & $4.434663^{*}$ & 7,248075 & $5.577965^{*}$ \\
2 & $-57,09406$ & 190,8549 & $2,66 \mathrm{E}-12$ & 4,526921 & 9,919294 & 6,71825 \\
3 & 54,28653 & 167,4774 & $3,31 \mathrm{E}-12$ & 4,66735 & 12,63868 & 7,906707 \\
4 & 145,9941 & 123,1693 & $5,97 \mathrm{E}-12$ & 5,094976 & 15,64527 & 9,38236 \\
5 & 255,882 & 129,9404 & $9,30 \mathrm{E}-12$ & 5,257197 & 18,38645 & 10,59261 \\
6 & 431,0378 & $\mathbf{1 7 8 . 9 9 1 3 *}$ & $6,60 \mathrm{E}-12$ & 4,466602 & 20,17482 & 10,85004 \\
\hline
\end{tabular}

\section{Cointegration Test Results}

Johansen's cointegration test on Inflation model (INFL) shows that there is 1 (one) cointegration equation at level 0.05 using 3 (three) assumption ie intercept and no trend. As for the Growth model (GRO) there are 2 (two) cointegration equations at the 0.05 level using the assumption of 3 (three) as intercept and no trend.

This test was done to see the long-term relationship in ECM equation model both INFL and GRO. The results of this test in Table 6 shows the existence of cointegration in both models by conducting unit root test with ADF approach on the residual value of each model with $5 \%$ significant level. 
Table 6.

Cointegration Test ECM

\begin{tabular}{cccc}
\hline Model & t- statistic & Mc Kinnon Critical Value & Prob \\
\hline INFL & $-4,170442$ & $-2,881978$ & 0,0010 \\
GRO & $-10,09135$ & $-2,881685$ & 0,0000 \\
\hline
\end{tabular}

\section{E. Correlation Test Results}

Variables on VAR / VECM should be sequenced according to the correlation between endogenous variables. The sequence of the two models can be seen in Table 7 below

Tabel 7.

Correlation Test Result

\begin{tabular}{c} 
CORRELATION \\
\hline $\mathrm{INFL}=$ FRB, IM, FM, ADM, EXCH, VFP, PLS, GOLD, XINFL, INT \\
GRO = FRB, IM, XINFL, FM, EXCH, ADM, PLS, VFP, INT, GOLD
\end{tabular}

\subsection{Vector Error Correction Model (VECM) Result}

\section{A. Inflation (INFL) Model}

The results of IRF and FEVD can be seen in Figure 4 below. The IRF results show that the variables that increase inflation or financial crisis are interest rate (INT), frictional resereve banking (FRB), administred price (ADM), and volatile food (VFP), while PLS and GOLD variables which are Islamic variables decrease inflation or financial crisis. FEVD results show that INT provides the largest portion of the inflation or financial crisis (21.87\%), followed by ADM (5.17\%) while PLS reduces inflation or financial crisis by $0.42 \%$ and GOLD by $0.007 \%$

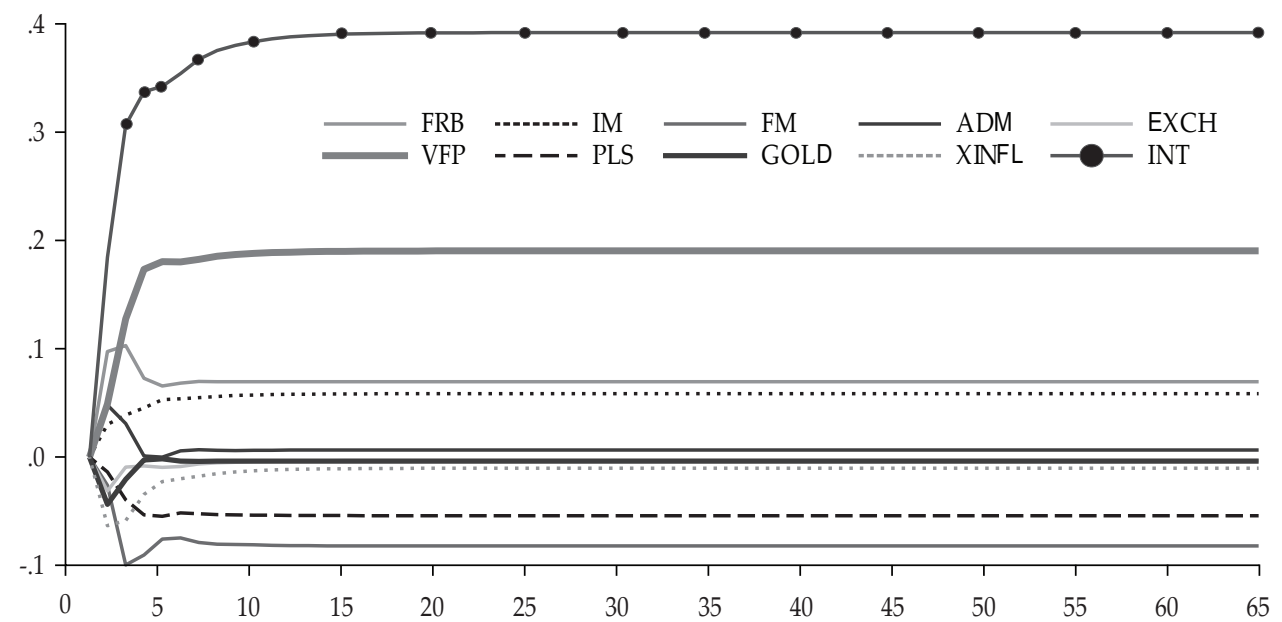

Figure 4.

The result of IRF (left) and FEVD (right) on Inflation (INFL) Model 


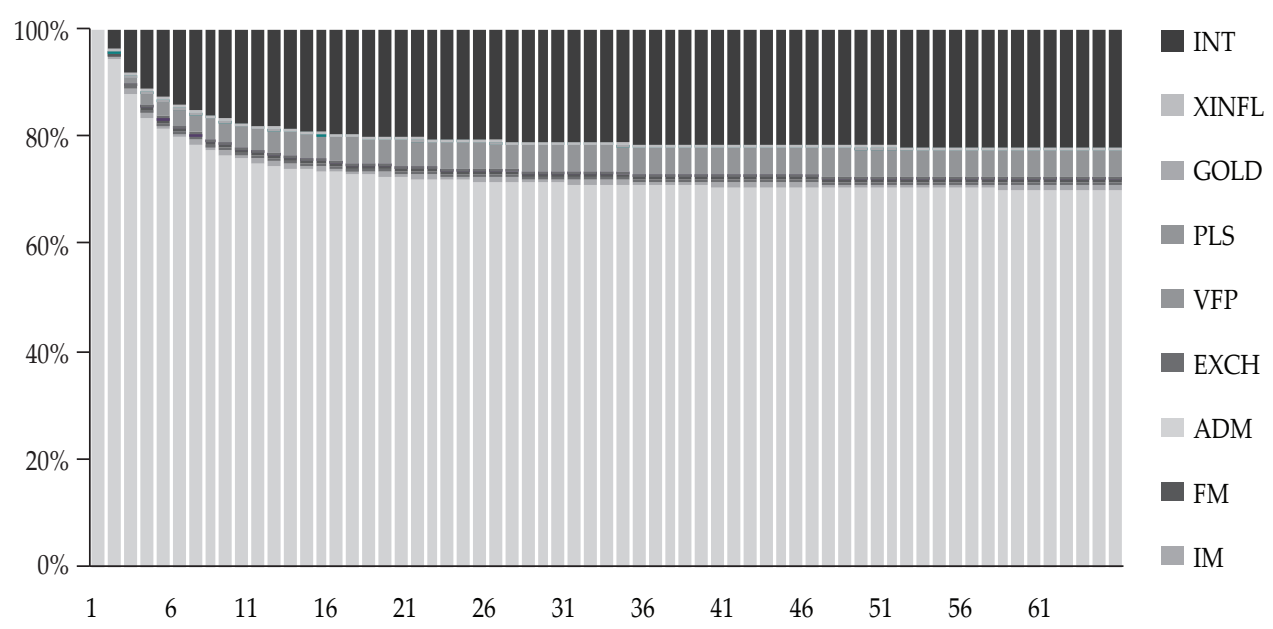

Figure 4.

The result of IRF (left) and FEVD (right) on Inflation (INFL) Model (Continued)

The summary results of VECM (IRF and FEDV) of the INFL model can be seen in Table 8. The variables INT, ADM, VFP, and FRB contribute positively to an increase in inflation or financial crisis, while PLS and GOLD contribute negatively into inflation or financial crisis. The IM variables also contribute positively to inflation or financial crisis, because IM is a proxy of M1 where M1 are the accumulation of $\mathrm{M} 0$ and demand deposits that are also part of the frictional reserve banking. Increased inflation or financial crisis caused by IM also in accordance with research Ascarya (2013). While the anomalies that occur between FM and IM are proxies with M0 and M1 also occur in Ascarya (2009a) study where FM contribute negatively and IM contribute positively to inflation or financial crisis. This can happen due to M0 being created without any backing up or created by out of nothing so as not being able to capture the essential difference of both variables while IM is created with $100 \%$ gold reserves (Ascarya, 2009a).

Furthermore, EXCH variables though contribute to lower inflation or crisis effect is smaller and longer stable compared with GOLD. EXCH contributes $0.005 \%$, is permanent or stable in the 33rd period while GOLD is a single currency proxy of $0.007 \%$, and is faster stable in the 19th period. Increased currency appreciation can reduce the inflation rate of a country that tends to import. In addition, XINFL variable that should have a positive effect on inflation or financial crisis in this study actually gives the opposite effect though with a very small portion of $0.04 \%$. It can be happened if the contribution of the variable is so small that when it is simultaneously implanted then the variables can have the opposite effect. Evidence can be seen when XINFL's positive influence on itself and when impulse is simultaneously negative, Rusydiana (2009) also shows that the influence of expectation is negative in inflation but in Ascarya (2013) study expectation gives positive influence to inflation. 
Table 8.

Summary of IRF and FEVD Results of the INFL Model

\begin{tabular}{llc}
\hline \multicolumn{1}{c}{ INFL } \\
\hline \multicolumn{1}{c}{ VARIABLE } & \multicolumn{1}{c}{ CONVENTIONAL } & ISLAMIC \\
\hline Behavior & XINFL (-) $0.04 \%$ & $\mathrm{n} / \mathrm{a}$ \\
External & EXCH (-) $0.005 \%$ & GOLD (-) $0.007 \%$ \\
Governance & ADM (+) $0.013 \%$ & $\mathrm{n} / \mathrm{a}$ \\
Monetary \& & INT (+) $21.87 \%$ & PLS (-) $0.42 \%$ \\
Macro prudential & FRB (+) $0.74 \%$ & $\mathrm{n} / \mathrm{a}$ \\
& FM (-) $0.99 \%$ & IM (+) $0.48 \%$ \\
Fiscal & VFP (+) $5.17 \%$ & $\mathrm{n} / \mathrm{a}$ \\
\hline
\end{tabular}

\subsection{Result and Testing Error Correction Model (ECM) \\ 4.3.1. Estimation Result ECM}

Table 9.

The result of ECM on Inflation (INLF) and Growth (GRO) Model

\begin{tabular}{|c|c|c|c|c|}
\hline \multirow{3}{*}{ VARIABLE } & \multicolumn{2}{|c|}{ INFL MODEL } & \multicolumn{2}{|c|}{ GRO MODEL } \\
\hline & \multicolumn{2}{|c|}{ ECM Coefficient } & \multicolumn{2}{|c|}{ ECM Coefficient } \\
\hline & Short Run & Long Run & Short Run & Long Run \\
\hline FRB & 0,019863 & $0.35656^{* * *}$ & $-0,031696$ & 0,010884 \\
\hline FM & $0.034396^{* * *}$ & 0,030954 & $-0,012443$ & $-0,006511$ \\
\hline $\mathrm{IM}$ & $-0.058355^{* * *}$ & $-0,044784$ & $0.29913^{* *}$ & $0.296627^{* *}$ \\
\hline INT & $0.00442^{* * *}$ & 0,001913 & 0,004299 & $-0.012892^{* *}$ \\
\hline PLS & $-0.000913^{* * *}$ & $-0,000369$ & $0.006193^{* * *}$ & $0.006363^{* *}$ \\
\hline $\mathrm{EXCH}$ & 0,008774 & $-0,020137$ & 0,040317 & 0,048868 \\
\hline GOLD & $0.020509^{* * *}$ & $0.017636^{* * *}$ & $-0.053939^{*}$ & $-0.048372^{* * *}$ \\
\hline $\mathrm{ADM}$ & $0.0696^{* * *}$ & $0.132168^{* * *}$ & $-0,013847$ & $-0.041666^{*}$ \\
\hline VFP & $0.029235^{* * *}$ & $0.022167^{* * *}$ & $-0.073809^{*}$ & $-0,019383$ \\
\hline XINFL & 0,000103 & $-0,001118$ & $-0,834612$ & 0,00177 \\
\hline ECT & \multicolumn{2}{|c|}{$-0.231346^{* * *}$} & \multicolumn{2}{|c|}{$-0.755445^{* * *}$} \\
\hline R2 & 0,683246 & 0,997429 & 0,494498 & 0,94148 \\
\hline ADJ R2 & 0,656649 & 0,997235 & 0,452051 & 0,93708 \\
\hline Prob(F-Statistic) & 0,000000 & 0,000000 & 0,000000 & 0,000000 \\
\hline D-W & $1,609,846$ & 0,648159 & $1,983,946$ & $1,673,308$ \\
\hline Prob (Ser.Corr) & \multicolumn{2}{|c|}{$0.0000^{*}$} & \multicolumn{2}{|c|}{0,0502} \\
\hline Prob (hetero) & \multicolumn{2}{|c|}{0,1543} & \multicolumn{2}{|c|}{0,2739} \\
\hline
\end{tabular}

*** Sig. 1\%, ${ }^{* *}$ Sig. $5 \%$, *Sig 10\%

Serial correlation of INFL equations has been treated using Newey-West Option 
Table 9 shows the long and short-term results of ECM on the INFL model. Conventional variables such as FM, INT, EXCH, ADM and VFP have a positive effect on the inflation rate or financial crisis at a real $1 \%$ level in the short term; this means that when FM, INT, EXCH, ADM and VFP increases then inflation or financial crisis will increase. Conversely Islamic variables such as IM and PLS have a negative effect on the significant level of $1 \%$ so that increasing IM and PLS will reduce inflation or financial crisis. Another important information is the Error Correction Term (ECT) in the inflation equation model is also negative and less than one (-0.231346) and significant at $1 \%$ level, this shows that as much as $23.13 \%$ deviation corrected each month, which means the process of adjustment (speed of adjustment) takes 4.32 months to reach its equilibrium condition.

Long-term estimates in Table 9 show the variables FRB, ADM, and VFP at a significant level of $1 \%$ have a positive effect on inflation or financial crisis in the long run. This means an increase in FRB, ADM, and VFP will increase inflation or financial crisis. In this research, GOLD variable has a significant effect on inflation or financial crisis both in long term and in short, which means the increase of gold price will increase inflation or financial crisis. This could be due to the position of gold today as a commodity rather than as a currency so that the behavior of variables is also different. Gold also becomes an economic indicator or behavior of society on economic condition. When the gold price rises this shows that expectations of inflation or recession is happening, so to keep their value of money, economic actors immediately hedge by buying gold because gold is a good instrument of store of value is also stable.

Furthermore, Table 9 shows the ECM estimation results in the GRO equation model that only one conventional variable (VFP) negatively affects the output growth or financial crisis in the short term so that when the VFP increases then output growth or financial crisis will decrease while the increase in Islamic variables such as PLS (1\% significant level) and IM (5\% significant level) will increase output growth or financial crisis. In this study ECT variable also negative and significant indicates the existence of error correction every month menunju balance of $75.5 \%$ per month for 1.32 months.

In the long run, conventional variables such as INT (5\% significant level) and VFP (significant level of 10\%) significantly negatively affect or decrease the growth of output or financial crisis while in Islamic variables IM and PLS have a positive effect or increase output growth or financial crisis on $5 \%$ significant level. In this study, the GOLD variable has a negative effect on the output growth or financial crisis in the long and short term, as explained above that the gold position today is not as currency but commodity so that the behavior of variables will be different as already described in the previous INFL model.

\subsection{Results and Testing of Autoregressive Distributed-Lag Model (ARDL)}

The stationary test result of ARDL model was done the same as the previous stationeritas test method that is VECM and ECM. Test results can be seen in Table 1. Overall, the stationary results of all variables are at the first difference level. Meanwhile, the bound test was performed to see whether there is a longterm relationship to the model or not by looking for the presence or absence of 
cointegration by comparing the F statistic value with the upper limit value in the Pesaran table. Bound Test Results both INFL and GRO models show that there is cointegration in the equation as in table 10.

Table 10.

Bound Test

\begin{tabular}{ccccc}
\hline Model & F- statistic & Significant & I0 Bound & I1 Bound \\
\hline INFL & 11,67699 & $1 \%$ & 2,84 & 4,1 \\
GRO & 10,58274 & $1 \%$ & 2,84 & 4,1 \\
\hline
\end{tabular}

The result of ARDL estimation on INFL equation model in Table 11 shows that in the short term conventional variables such as XINFL and FM significantly at the significant level of $1 \%$ have a positive effect or increase inflation or financial crisis. While Islamic variables, IM has a negative effect or decrease inflation or financial crisis significantly with a significant level of $10 \%$. Furthermore, the ECT variable is also negative between 0 and -1 and it shows significant that the speed of adjusment against the deviation correction to achieve the equilibrium of $28.3 \%$ per month for 3.54 months.

Table 11.

The result of ARDL on Inflation (INLF) and Growth (GRO) Model

\begin{tabular}{|c|c|c|c|c|}
\hline \multirow{3}{*}{ VARIABLE } & \multicolumn{2}{|c|}{ INFL } & \multicolumn{2}{|c|}{ GRO } \\
\hline & \multicolumn{2}{|c|}{ ARDL Coefficient } & \multicolumn{2}{|c|}{ ARDL Coefficient } \\
\hline & Short Run & Long Run & Short Run & Long Run \\
\hline FRB & $-0,670018$ & $1,027,871$ & $-434,078$ & $-4,866,694$ \\
\hline FM & $0.631543^{* * *}$ & $2.88647^{* * *}$ & $-2.181136^{* *}$ & $-4.205475^{* * *}$ \\
\hline IM & $-0.428308^{*}$ & $-1.515869^{*}$ & $6.265144^{* * *}$ & $7.024206^{* * *}$ \\
\hline INT & $-0,006685$ & 0,003367 & 0,159537 & 0,01583 \\
\hline D(INT(-1)) & & & 0,224009 & \\
\hline PLS & 0,00049 & $0.004623^{* * *}$ & 0,0336 & $-0,021856$ \\
\hline D(PLS(-1)) & & & $0.041209^{*}$ & \\
\hline $\mathrm{EXCH}$ & 0,067893 & 0,240287 & 0,420462 & 0,471404 \\
\hline GOLD & $0.020343^{* * *}$ & $0.030718^{* * *}$ & $-0.033512^{* *}$ & $-0.037572^{* *}$ \\
\hline ADM & 0,579926 & $1.144875^{* * *}$ & $-0.548519^{* *}$ & $-0.614976^{* * *}$ \\
\hline VFP & 0,020296 & $-0,013775$ & $-0,000473$ & $-0,00053$ \\
\hline XINFL & $0.007158^{* * *}$ & $-0,004265$ & $-0,021541$ & $-0.024151^{*}$ \\
\hline ECT & $-0.282549^{* * *}$ & - & $-0.891936^{* * *}$ & - \\
\hline R2 & \multicolumn{2}{|c|}{0,999654} & \multicolumn{2}{|c|}{0,952923} \\
\hline ADJ R2 & \multicolumn{2}{|c|}{0,999601} & \multicolumn{2}{|c|}{0,946469} \\
\hline Prob(F-Statistic) & \multicolumn{2}{|c|}{ 0,000000 } & \multicolumn{2}{|c|}{0,000000} \\
\hline D-W & \multicolumn{2}{|c|}{182,419} & \multicolumn{2}{|c|}{$2,052,893$} \\
\hline Prob (Ser.Corr) & \multicolumn{2}{|c|}{0,1943} & \multicolumn{2}{|c|}{0,6724} \\
\hline Prob (hetero) & \multicolumn{2}{|c|}{0,204} & \multicolumn{2}{|c|}{0,1764} \\
\hline
\end{tabular}

*** Sig. $1 \%,{ }^{* *}$ Sig. $5 \%,{ }^{*} \operatorname{Sig} 10 \%$ 
In the long run, conventional variables that have positive or inflationary effect are FM and ADM at $1 \%$ level while IM has negative effect on inflation or crisis at $10 \%$ significant level. In this approach, the varabel GOLD behaves similarly to the ECM approach. Similar to the previous explanation, the current position of gold that becomes a non-currency commodity can show such behavior. The PLS variable in the long run increases the inflation even though it is very small that is $0.0046 \%$. This is in accordance with Ascarya (2009a) that PLS can also increase inflation but the contribution of INT is much larger, refers to the conventional benchmark of Indonesian bank interest rates so that real sector index is needed to see the actual effect of PLS.

The result of ARDL estimation of GRO model in Table 11 shows that in the short term, the variables that have an effect on decreasing output growth or financial crisis are FM and ADM with 5\% significant level. Meanwhile, the Islamic variable which has negative effect or increase the growth or financial crisis is IM at the significant level $1 \%$ and PLS (-1) at a significant level of $10 \%$. The significance of ECT (-0.891936) indicates that the correction of deviations per month is $89.2 \%$ and the speed of adjustment to obtain equilibrium is 1.12 months.

The variables that negatively affect or decrease the output growth or financial crisis in the long term are FM (1\% significant level), ADM (1\% significant level), and XINFL ( $10 \%$ significant level). In this study, the GOLD variable is significantly either $10 \%$ or $5 \%$ of the best behavior of the initial hypothesis. As already explained in the ECM equation, the gold position today is not as a currency but a commodity so that it will obviously give a different effect.

\section{CONCLUSIONS AND RECOMMENDATIONS}

\subsection{Conclusions}

This research has been conducted on reviewing the root cause of the financial crisis from the Islamic perspective using three approaches namely ECM, ARDL and VECM on two equation model, inflation (INFL) and output growth (GRO). It can be concluded that the consistent root causes of the problems that lead to financial crises with the three approaches are the interest rate (INT) i.e. ribâ, which at the same time prove that violations of Allah's rules affect the economic damage. This means a true structural problem occurs in conventional economic systems. Furthermore, the consistency of ADM and VFP variables leading to financial crisis indicates that the government should minimize its role in price control but play a role in better management of commodity management.

\subsection{Policy Recommendations}

Firstly, the monetary policy has to the return the main function of money as a medium of exchange with 100 percent gold reserve as Bretton Woods's agreement. Secondly, the determination of interest rates at zero percent as the optimum level in the case of Indonesia to curb inflation and induce output growth. Thirdly, the use of the real sector index as a benchmark of profit loss sharing ratio to reflect the actual effect as well as avoid displaced commercial risk in the financial sector. 
Furthermore, improving the quality of commodity management and reducing price intervention by government is essential to avoid crisis. In addition, increasing the quality of Islamic human resources who understand the Islamic values properly through education is needed to create an economic system in accordance with Islamic Shari'a especially in the government system as policy maker. Finally, we recommend using the better Islamic proxy variables, especially the proxy of Islamic Money, to capture the real influences of the economy.

\section{REFERENCES}

Alqur'an. (2010). Syamil Al-qur'an and Terjemahan Tafsir Per Kata. Sygma: Bandung, Indonesia.

Ahmed, H. (2009). Financial Crisis: Risks and Lessons for Islamic Finance. ISRA International Journal of Islamic Finance, 1(1), 7-32.

Al Misri, R. (2001). Al Azmah Al Maliyah, Hal Najidu Laha Fil Islam Min Hall?, First Edition. Damaskus: Dar Qalam.

Al Umrani, A. (2007). Al Manfa'atu fil Qardh (2 ${ }^{\text {nd }}$ Edition). Dammam: Dar Ibnu Al Jawzi.

Ascarya. (2009). Forgotten Root Causes of The Crisis. IPEBI Serial Roundtable Discussion on "Krisis Keuangan Global and Outlook Perekonomian Indonesia 2009: Tantangan Bagi Pegawai Bank Indonesia".

Ascarya. (2009a). The Determinants of Inflation under Dual Monetary System in Indonesia. Working Paper Bank Indonesia 2009.

Ascarya. (2013). Analysis of Financial Crisis and How to Prevent It in Islamic Perspective using Vector Error Correction Model. Paper presented at the $9^{\text {th }}$ International Conference on Islamic Economics and Finance, Istanbul, Turkey.

Ascarya. (2015). Analysis on Financial Crisis and How to Prevent It Using the Islamic Perspective. Dissertation, Trisakti University, Indonesia.

Bianchi, J. \& Mendoza, E. (2011). Over Borrowing, Financial Crises and 'Macro prudential' Policy. IMF Working paper, WP/11/24.

Claessens, S. \& M. Ayhan K. (2013). Financial Crises: Explanation, Types, and Implications. IMF working paper, WP/13/28

Dar, Fayaz Ahmad \& Iqbal Ahmad Hakeem. (2012). The Global Financial Crisis And The Islamic Financial Solution. International Monthly Refereed Journal of Research In Management \& Technology, 1, December 2012, 94-103,

Davies, G. (1996). A History of Money from Ancient Times to the Present Day. United Kingdom: Univesity of Wales Press.

Enders, R. F. \& Granger, C. W. J. (2004). Econometric Time Series (2 ${ }^{\text {nd }}$ Edition). New York: John Wiley and Sons, Inc.

Gujarati, D. (2004). Basic Econometrics. New York: The MCGraww-Hill Companies.

International Monetary Fund. (1998). World Economic Outlook, May 1998, International Monetary Fund, Washingthon D. C. Retrieved from http://www. imf.org/

Insukindro, (1997). Ekonomi Uang and Bukti Teori and Pengalaman Di Indonesia. Yogyakarta: BPPE.

Laeven, L. \& Valencia, F. (2008). Systemic Banking Crises: A New Database. IMF Working Paper, WP/08/224. 
Laeven, L., \& Valencia, F. (2013). Systemic Banking Crises Database. IMF Economic Review, 61(2), 225-270.

Lietaer, B., Ulanowicz, R., \& Goerner, S. (2009). Options on Managing a Systemic Banking Crisis. S.A.P.I.EN.S Journal, 2(1).

Mirakhor, A. \& Slomo. (2010). The Global Financial Crisis and its Implications for the Islamic Financial Industries. International Journal of Islamic and Middle Eastern Finance and Management, 3(4), 372-385.

Pesaran \& Shin. (1995). An Autoregressive Distributed Lag Model Approach to Cointegration Analysis. Paper presented at the Symposium at the Centennial of Ragnar Frisch, The Norwegian Academy of Science and Letter, Oslo, March 3-5, 1995.

Rusydiana, A. S. (2009). Determinan Inflasi Indonesia: Sebuah Perbandingan Pendeketan Islam and Konvensional. Thesis, STEI Tazkia, Indonesia.

Sakti, A. (2007), Sistem Ekonomi Islam: Jawab atas kekacauan atas Ekonomi Modern. Jakarta: Paradigma and Aqsha Publishing.

Tarmizi, E. (2013). Harta Haram Muamalat Kontemporer ( $5^{\text {th }}$ Edition). Bogor: PT. Berkat Mulia Insani. 